\title{
Variables controlling strength of lime stabilized jarosite waste
}

\author{
Chayan Gupta* and Arun Prasad
}

${ }^{*}$ Correspondence:

chayan.rs.civ14@itbhu.ac.in

Civil Engineering

Department, Indian Institute

of Technology (BHU),

Varanasi, India

\begin{abstract}
The study advocates the influence of lime $(L)$ and curing period $(t)$ on stabilization of jarosite waste. A number of laboratory strength tests [unconfined compressive $\left(q_{u}\right)$ and split tensile strength $\left(q_{t}\right)$ ] are conducted on artificially cemented jarosite-lime blends (lime $=2.5-10 \%)$ with different curing periods ( $t=7,28$ and 90 days). The outcomes indicate that both $q_{u}$ and $q_{t}$ increase nonlinearly with the increase in lime content and curing period, which is further justified by microstructural study that illustrates the occurrence of larger agglomeration in particles. In addition to these, a good correlation between $\mathrm{q}_{\mathrm{u}}$ and $\mathrm{q}_{\mathrm{t}}$ and $\mathrm{L}$ and $\mathrm{t}$ was possible by fitting the power function on the outcomes. Furthermore, a unique relationship between $q_{u}$ and $q_{t}$ is also developed, which is independent of $L$ and $t$ (i.e. $q_{t} / q_{u}=0.16$ ).
\end{abstract}

Keywords: Jarosite, Lime, Unconfined compressive strength, Split tensile strength, Microstructural study, Applications

\section{Introduction}

Currently, industrialization evolution is synonyms of any developing country, which runs on the way to become a developed country. But growth in this mechanization, the large level of waste and by-products are engendered. Worldwide, about 20 billion tons of total wastes are produced, wherein about 12 billion tons of wastes are generated from industrial progression, 4 billion tons produced in the form of municipal solid wastes (MSW), and the remaining 4 billion tons cover natural wastes in form of organic as well as inorganic waste $[4,19,20]$. For the disposal of the waste, the land disposal method is one of the widely adopted conventional methods, but the large production of wastes, the requirement of more precious land rises, thus the scarcity of land arises mostly.

Nowadays, various substitutes are active for solving this land scarcity problem. The waste management programs, which principally comprises, controlling the production of waste at their source; reduce, reuse and recycling (3-R) the waste; recovery of energy and eco-friendly disposal. Today, numerous wastes such as agricultural waste, marble and coal combustion residues, cement kiln dust, blast furnace slag, foundry waste, ceramics waste, glass waste, steel chips waste, building constructional waste and many more have been fruitfully exploited as stabilizing agents for advancement of

(c) The Author(s) 2018. This article is distributed under the terms of the Creative Commons Attribution 4.0 International License (http://creativecommons.org/licenses/by/4.0/), which permits unrestricted use, distribution, and reproduction in any medium, provided you give appropriate credit to the original author(s) and the source, provide a link to the Creative Commons license, and indicate if changes were made. 
the properties of conventional construction materials, with or without the addition of cementing agent as a binder.

Jarosite is a solid waste produced from hydrometallurgy operations involved in the extraction of Zinc. Due to large extraction of zinc worldwide, about 0.60 million tons of jarosite was released annually [2]. Numerous researchers are advocating their studies to explore the chances to reduce and utilize jarosite. Mymrin and Vaamonde [31], Mymrin et al. [32] reported the potential for emerging novel material subsequent from blends of jarosite, dump ferrous slag, and the Aluminum surface, with and without the addition of lime as well as Portland cement and concluded that the resulted composite maintains significant strength and water resistance. Chen and Dutrizac [15] advocated the mineralogical analysis of jarofix (jarosite with 1\% lime and 10\% cement) and observed that its consistency be contingent on the amount of jarosite and Portland cement in the blend. The study by Katsioti et al. [25] presented the chances of substituting the natural gypsum with jarosite in cement production. Asokan et al. [1-3] reported that jarosite waste could be immobilized by the development of composite products by blending of additional inorganic industrial wastes such as coal combustion and marble processing residues. Sinha et al. [34] presented the comparative analysis of jarofix with bottom ash and local clayey soil and concluded its potential in the various applications of civil engineering such as pavement and embankment and as a geotechnical material. Similarly, many more researchers $[13,16,17,28-30,35,36,39]$ have explored the chances to utilize the jarosite as a constructional material with or without blend of cement/lime as an additive.

From the aforesaid literature review, it is perceived that there is a lack of studies which show the bulk utilization of jarosite in the application of civil engineering. The current study makes a bridge to utilize jarosite waste with the blending of hydrated lime as a binder to stabilize the jarosite; thus, the stabilized product can be used proficiently in several areas of civil engineering.

\section{Scope and objectives}

In this study, the authors make an attempt to evaluate the geotechnical properties of lime stabilized jarosite waste to enhance the possibility to utilize this stabilized matrix as a construction material in various applications of civil engineering. The objectives of the study are:

- Explore the effect of different lime content (2.5-10\%) and curing period (7, 28 and 90 days) on the unconfined compressive strength and split tensile strength of jarosite waste.

- An assessment for engineer/user to choose the optimum amount of lime to arrive at the target compressive or tensile strength of jarosite-lime blends.

- Evaluate relationship among unconfined compressive strength $\left(\mathrm{q}_{\mathrm{u}}\right)$ or split tensile strength $\left(\mathrm{q}_{\mathrm{t}}\right)$ with various lime content $(\mathrm{L})$ and curing period $(\mathrm{t})$.

- Enhancing the possibility to concentrate either on tensile strength or on compressive strength for getting the desired results, an attempt has been made to formulate a unique scalar from $\mathrm{q}_{\mathrm{t}} / \mathrm{q}_{\mathrm{u}}$ ratio, (independent from $\mathrm{L}$ to $t$ parameters).

- Study the feasibility of stabilizing material to use as a subgrade material in pavement design. 


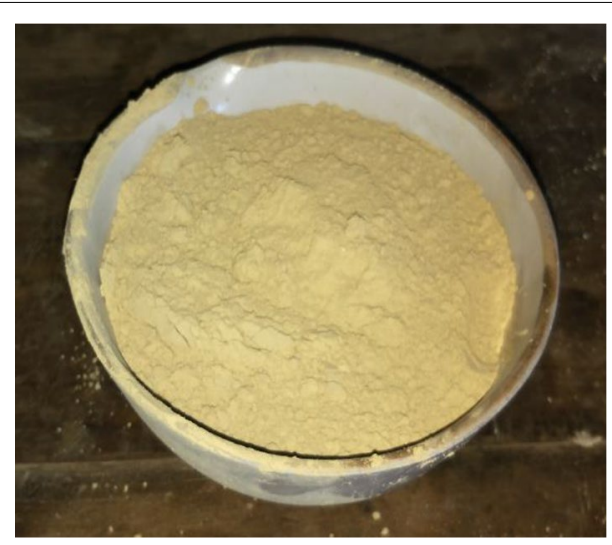

Fig. 1 A photograph of jarosite

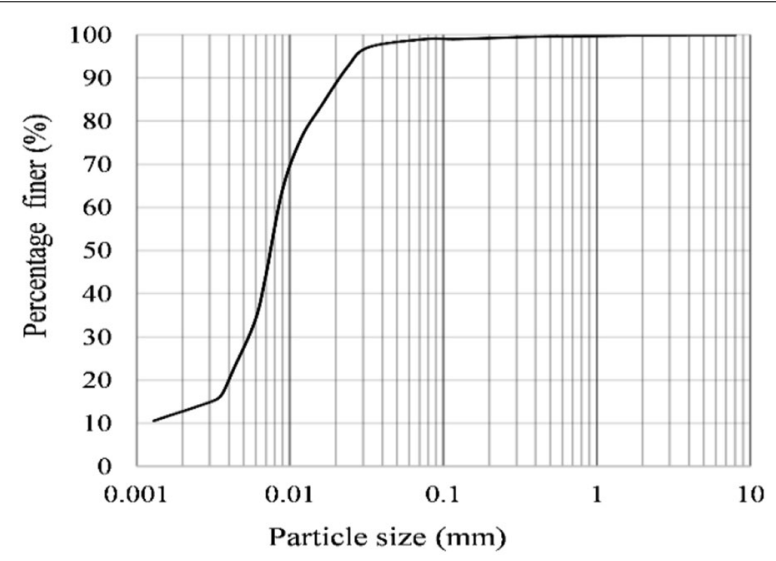

Fig. 2 Grain size distribution curve of jarosite

\section{Materials}

Jarosite

Jarosite is a solid waste produced from hydrometallurgy operations involved in extraction of Zinc, in which, initially the Zinc ore concentrate (contains $~ 50 \%$ zinc) is roasted at $900{ }^{\circ} \mathrm{C}$ and then exposed to leaching operation where iron residual (jarosite) is produced as a waste [37]; Mymrin and Vaamonde [21, 32]. In the current study, jarosite is collected from Hindustan Zinc Limited, Udaipur, Rajasthan (India). A photograph showing jarosite is presented in Fig. 1. As per American Society for Testing and Materials [11] D2487-11 soil classification system, jarosite is categorized as silty clay with high plasticity $(\mathrm{MH})$. The jarosite is usually found as yellowish-brown in color (Fig. 1). The consistency limits (liquid limit, plastic limit and plasticity index) of jarosite were determined as per ASTM [6] D4318-10. The particle size distribution was conducted in accordance with ASTM [8] D6913-04 (sieve analysis) and ASTM [10] D422-63 (hydrometer analysis) and is shown in Fig. 2. The specific gravity was found to be 2.77 (ASTM [7] D854-00). The differential free swell index (DFS) of jarosite was 18; thus the degree of expansiveness of jarosite is characterized as low IS: 2911-3 [23]. The compaction test is conducted as per ASTM [12] D698-12e1 and it was observed that the maximum dry 
Table 1 Index properties of jarosite

\begin{tabular}{ll}
\hline Properties & Values \\
\hline Liquid limit (\%) & 54 \\
Plastic limit (\%) & 32 \\
Plasticity index (\%) & 22 \\
Specific gravity & 2.77 \\
Silt (\%) & 85 \\
Clay (\%) & 15 \\
Maximum dry density $\left(\mathrm{Mg} / \mathrm{m}^{3}\right)$ & 1.13 \\
Optimum moisture content (\%) & 42 \\
Hydraulic conductivity $(\mathrm{cm} / \mathrm{s})$ & $1.7508^{*} 10^{-5}$ \\
Texture & Clayey silty \\
pH & 6.87 \\
Differential free swell index (\%) & 18 \\
\hline
\end{tabular}

Table 2 Chemical composition of jarosite

\begin{tabular}{lcl}
\hline Chemical composition & Value (\%) & Lime \\
\cline { 2 - 3 } & Jarosite & 4.29 \\
\hline Silica $\left(\mathrm{SiO}_{2}\right)$ & 6.75 & 1.48 \\
Alumina $\left(\mathrm{Al}_{2} \mathrm{O}_{3}\right)$ & 6.75 & 71.46 \\
Calcium oxide $(\mathrm{CaO})$ & 6.87 & 0.27 \\
Iron oxide $\left(\mathrm{Fe}_{2} \mathrm{O}_{3}\right)$ & 32.12 & - \\
Potassium oxide $\left(\mathrm{K}_{2} \mathrm{O}\right)$ & 0.74 & 15.48 \\
Magnesium oxide $(\mathrm{MgO})$ & 1.86 & - \\
Zinc oxide $(\mathrm{ZnO})$ & 9.18 & 4.56 \\
Total sulfer $(\mathrm{SO})$ & 31.80 & 0.47 \\
Lead oxide $\left(\mathrm{PbO}_{3}\right)$ & 1.91 & 0.03 \\
Sodium oxide $\left(\mathrm{Na}_{2} \mathrm{O}\right)$ & 0.63 & \\
\hline
\end{tabular}

density and optimum moisture content of the jarosite is $1.13 \mathrm{Mg} / \mathrm{m}^{3}$ and $42 \%$, respectively. The geotechnical characteristics and the results of chemical analysis of jarosite are listed in Tables 1, 2, respectively.

\section{Lime}

In this study, hydrated lime $\left[\mathrm{Ca}(\mathrm{OH})_{2}\right]$ is used as a cementitious additive, which is procured commercially. The specific gravity of lime is found to be 2.48 . The Hydrated lime is chemically derived from quicklime $(\mathrm{CaO})$ by reacting with water $\left(\mathrm{H}_{2} \mathrm{O}\right)$. In current practice, hydrated lime is typically used in the stabilization programs.

\section{Testing methodology}

Two types of strength test, unconfined compressive and split tensile strength test, have been carried out in the laboratory on jarosite stabilized with lime added at a rate of 2.5, 5.0, 7.5 and $10 \%$ by dry weight of jarosite. The jarosite transported from the zinc industry is first dried in an oven for $24 \mathrm{~h}$ at $105^{\circ} \mathrm{C}$, and after that, it is grounded to break all lumps before used for testing. 


\section{Compaction tests}

In accordance with ASTM [12] D698-12e1, a Mini Compaction Mold (developed by Sridharan and Sivapullaiah [38]) is used for compaction test. For each compaction test, about $200 \mathrm{~g}$ of the jarosite-lime mixture is used. The required amount of water is added to the blend and then mixed thoroughly. The blend is then kept aside for sufficient time to gain moisture equilibrium. After that, the blend is compacted in a compaction mold, $38.1 \mathrm{~mm}$ in diameter and $100 \mathrm{~mm}$ in height, in three layers and giving 36 blows to each layer through a drop hammer. After compaction, the compacted sample is removed from the mold, its bulk unit weight recorded and calculating the dry unit weight.

\section{Strength tests}

Unconfined compressive strength as well as split tensile strength tests are a fundamental, quick and widely accepted experimental program for predicting the shear strength and tensile strength of stabilized material as per ASTM [9] D2166-06 and ASTM [5] D-3967, respectively.

\section{Sample preparation for strength test}

For the preparation of the samples for strength test, the required amounts of jarosite and lime were measured [as per maximum dry density (MDD)] and blended in a dry state to obtain a uniform mixture. Afterward, the required quantity of water [as per optimum moisture content (OMC)] was added and again blended thoroughly. The samples for unconfined compressive strength (UCS) were prepared in a mold, $38 \mathrm{~mm}$ in diameter and $76 \mathrm{~mm}$ in height, i.e., with an aspect ratio of 2. Similarly, for split tensile strength test, the samples were prepared in a testing mold $38 \mathrm{~mm}$ in diameter and $19 \mathrm{~mm}$ in length, i.e., with an aspect ratio of 0.5. The samples were prepared by thoroughly compacting the jarosite-lime blend in three equal layers in the mold. Before pouring the blended mixture in the mold, a thin coating of lubricant was applied to the internal surface of the mold to lessen the friction between the mold and the blended mixture. Thus, the chances of any type of disturbance during the compaction and its removal was minimized. For proper bonding between the layers, enough scraping was made on the surface before placing the next layer. With the help of hydraulic sample extractor, the compacted sample was removed from the mold, and then the sample was put in a plastic bag (to minimize moisture loss due to evaporation) and retained in a desiccator for curing for 7,28 , and 90 days. After curing, both the tests were carried out at a strain rate of $1.25 \mathrm{~mm} / \mathrm{min}$. As per the standard practice, the results were accepted only if the standard deviation in the strength of three individual samples molded at same moisture content didn't vary by more than $10 \%$ from their mean strength.

\section{Microstructural analysis (SEM-EDX)}

In the microstructural analysis, scanning electron microscope (SEM) corresponding to energy-dispersive X-ray spectroscopy of various jarosite-lime blends are carried out using high resolution scanning electron microscope (SUPRA 40, Zeiss 4.0). A small portion of sample after strength tests was oven dried and used for SEM studies. For examining the change in the packing nature (due to pozzolanic reactions) of stabilized blends, several SEM images were recorded at different magnifications. 


\section{Results and discussion}

\section{Effect of lime on compaction parameters}

The moisture content-dry density curves of jarosite blended with varying percentage of hydrated lime $(2.5,5.0,7.5$ and 10\%) are presented in Fig. 3a, and the variation in the MDD and OMC of jarosite blended with varying percentage of lime is shown in Fig. 3b. It was observed that MDD and OMC of the jarosite were $1.13 \mathrm{Mg} / \mathrm{m}^{3}$ and $42 \%$, respectively, which changed after blending with lime. There is an increase in the OMC and a decrease in the maximum dry density. Due to lesser specific gravity and higher surface area of lime compared with jarosite, more water was required to lubricate the partials of the composite blend to attain its MDD and OMC. Thus, it resulted in the increase in the OMC and decrease in the MDD.

\section{Effect of lime on the strength characteristics}

The variations in the stress-strain curves of UCS and split tensile strength tests for various jarosite-lime blends (2.5-10\%) along with various curing periods $(7,28$, and 90 days) are presented in Figs. 4, 5, respectively. It can be seen in the figures that higher the curing period and lime content, higher is the brittleness of blended sample over untreated ones. It is interesting to note from Figs. 4, 5 that with the increase in the lime content, a substantial enhancement in both the types of strengths (UCS and tensile) are obtained. The addition of a binder (lime) improves the pozzolanic activity, thus the formation of cemented compounds that enhance extra strength to the jarosite-lime blend is also validated in Fig. 9. With the addition of lime in jarosite, the aluminous and silicious minerals present in jarosite react with calcium present in lime to form calcium silicates hydrate $[\mathrm{C}-\mathrm{S}-\mathrm{H}]$ and aluminates hydrate bonds $[\mathrm{C}-\mathrm{A}-\mathrm{H}]$ as shown in Fig. 10. Many researchers $[18,24,33]$ have reported similar findings.

The results presented in Fig. 4 show that the UCS of jarosite-lime blends containing $10 \%$ lime is increased from $187 \mathrm{kPa}$ (untreated jarosite) to 1152,1985 , and $3641 \mathrm{kPa}$ at 7 , 28 and 90 days curing period respectively. Similarly, the split tensile strength of jarositelime blends containing $10 \%$ lime is increased from $42 \mathrm{kPa}$ (untreated jarosite) to 117 , 208, and $356 \mathrm{kPa}$ at 7, 28 and 90 days curing period respectively (Fig. 5). Numerous past studies have also confirmed that the addition of lime modifies the composition of the particles along with mineralogy, their physicochemical properties as well as the strength properties of stabilized fine-grained materials [14, 18, 22, 41].

The parametric studies of various stabilized jarosite-lime blends tested for UCS and split tensile strength tests are generalized in which a relationships between the UCS $\left(\mathrm{q}_{\mathrm{u}}\right)$ as well as the split tensile strength $\left(\mathrm{q}_{\mathrm{t}}\right)$ with various curing period $(\mathrm{t})$ and lime content (L) are formulated from expression shown in Figs. 6, 7 respectively. For comprehensive evaluation of outcomes, an adjusted power model has been fitted with a power of 0.45 to the curing period $(\mathrm{t})$.

Good correlations, varying between $R^{2}=0.97-99$, have been observed in the derived relationships. These relationships have been shown in the figures itself.

From the formulated equations presented in Figs. 6, 7, it can be concluded that the disparity in strength of stabilized jarosite-lime blends depends directly upon the curing period $(\mathrm{t})$ and lime content $(\mathrm{L})$. It can also be advocated that above equations have only a scalar variable, which is affected only by the type of strength test (unconfined 


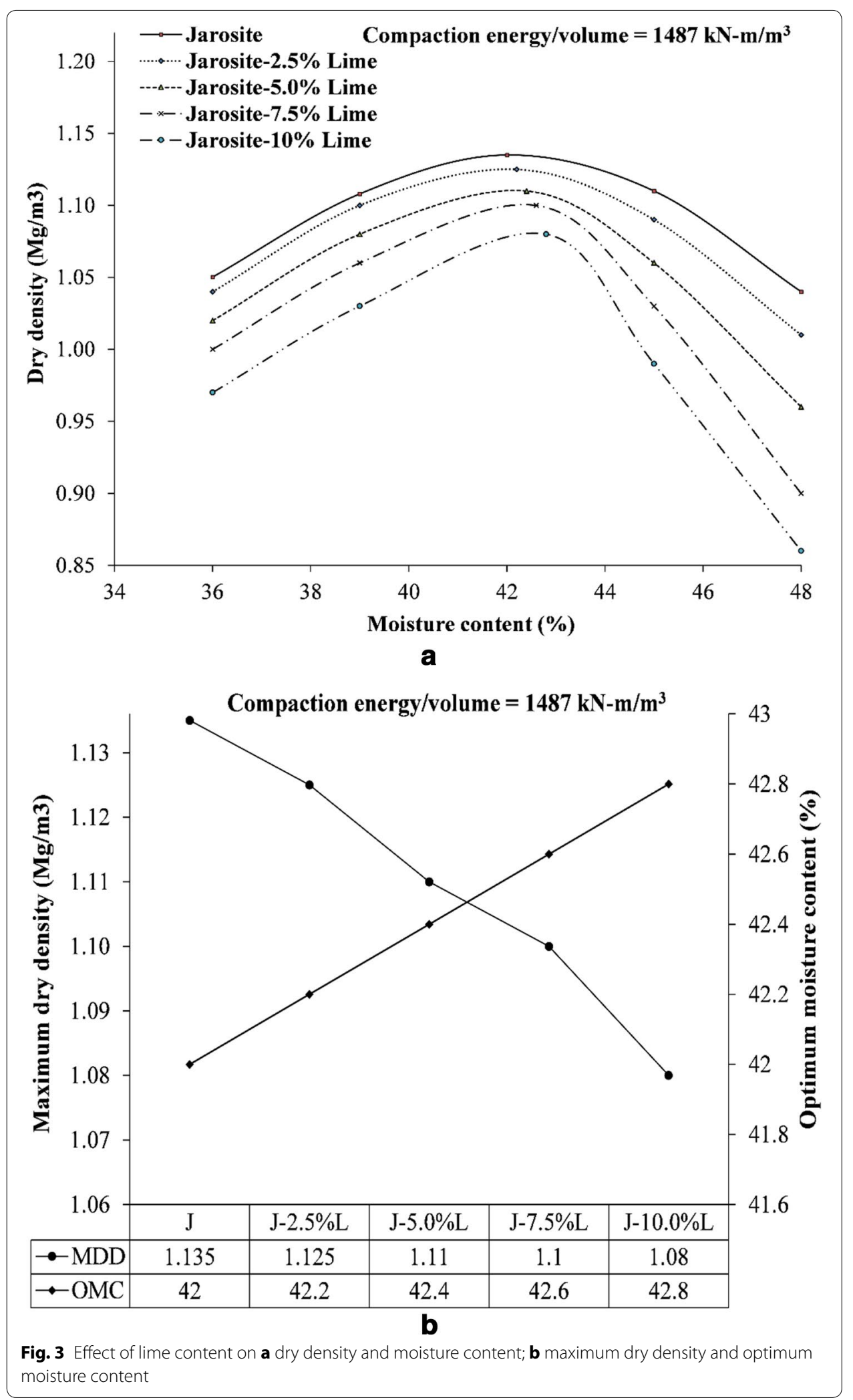




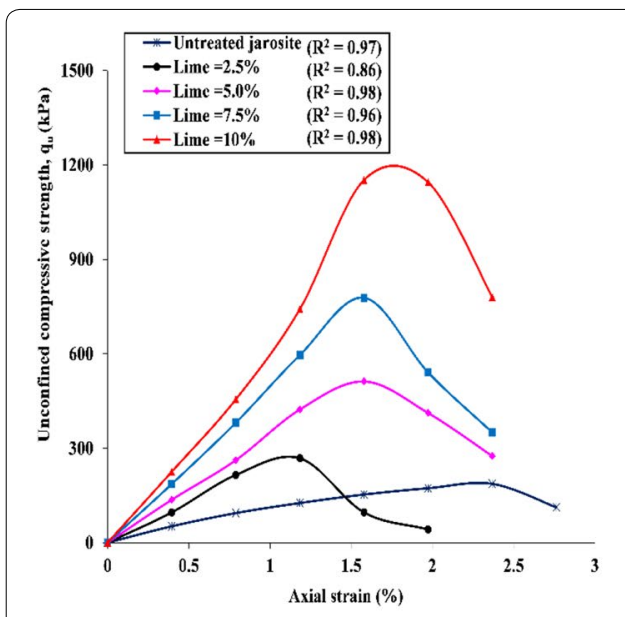

a

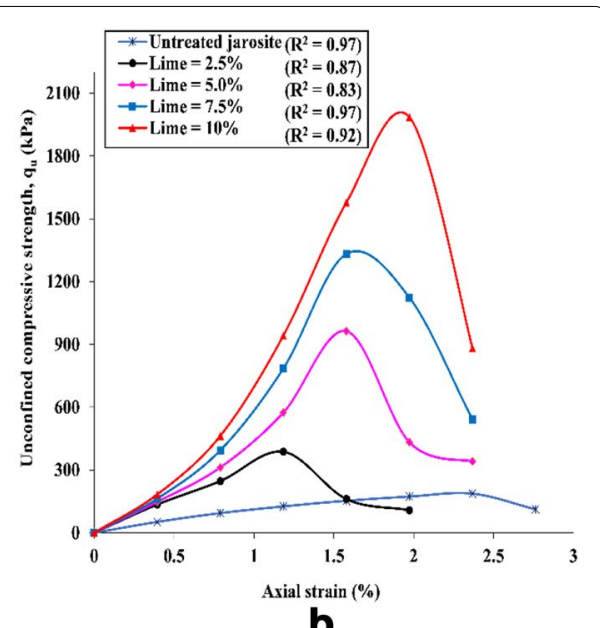

b

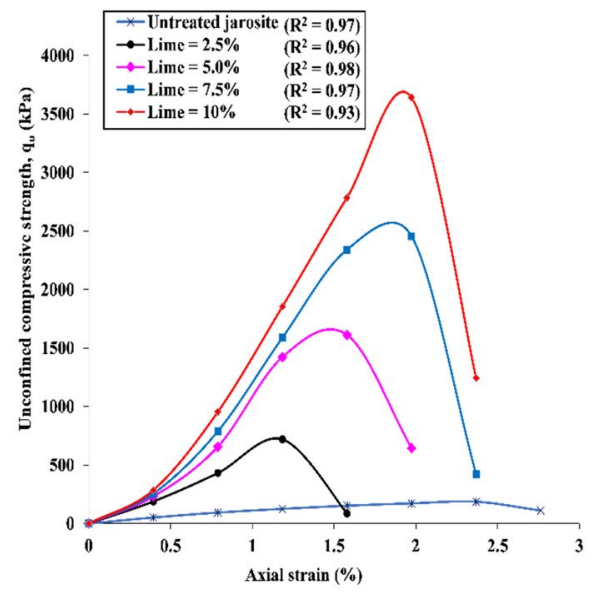

C

Fig. 4 Effect of lime content on Stress-Strain behaviour of UCS samples cured at a 7, b 28, and $\mathbf{c} 90$ days

compressive or split tensile) and lime content. Thus, unique relationships can also be established among $\mathrm{q}_{\mathrm{u}}$ or $\mathrm{q}_{\mathrm{t}}$ with $\mathrm{t}$, and $\mathrm{L}$ as presented in Fig. 8 .

For easy evaluation of results, an adjusted power model is fitted with a power of 1.0 for lime content (L). Hence,

$$
\begin{aligned}
& \mathrm{q}_{\mathrm{u}}=44.22(\mathrm{t})^{0.45}(\mathrm{~L})^{1.0} \\
& \mathrm{q}_{\mathrm{t}}=7.07(\mathrm{t})^{0.45}(\mathrm{~L})^{1.0}
\end{aligned}
$$

Further, these two Eqs. (1 and 2) have been presented by a single generalized equation Eq. (3), which can be utilized for determination of both unconfined compression strength $\left(\mathrm{q}_{\mathrm{u}}\right)$ and split tensile strength $\left(\mathrm{q}_{\mathrm{t}}\right)$.

$$
q_{u \leftrightarrow q_{t}}(k P a)=A(t)^{a}(L)^{b}
$$

where, 

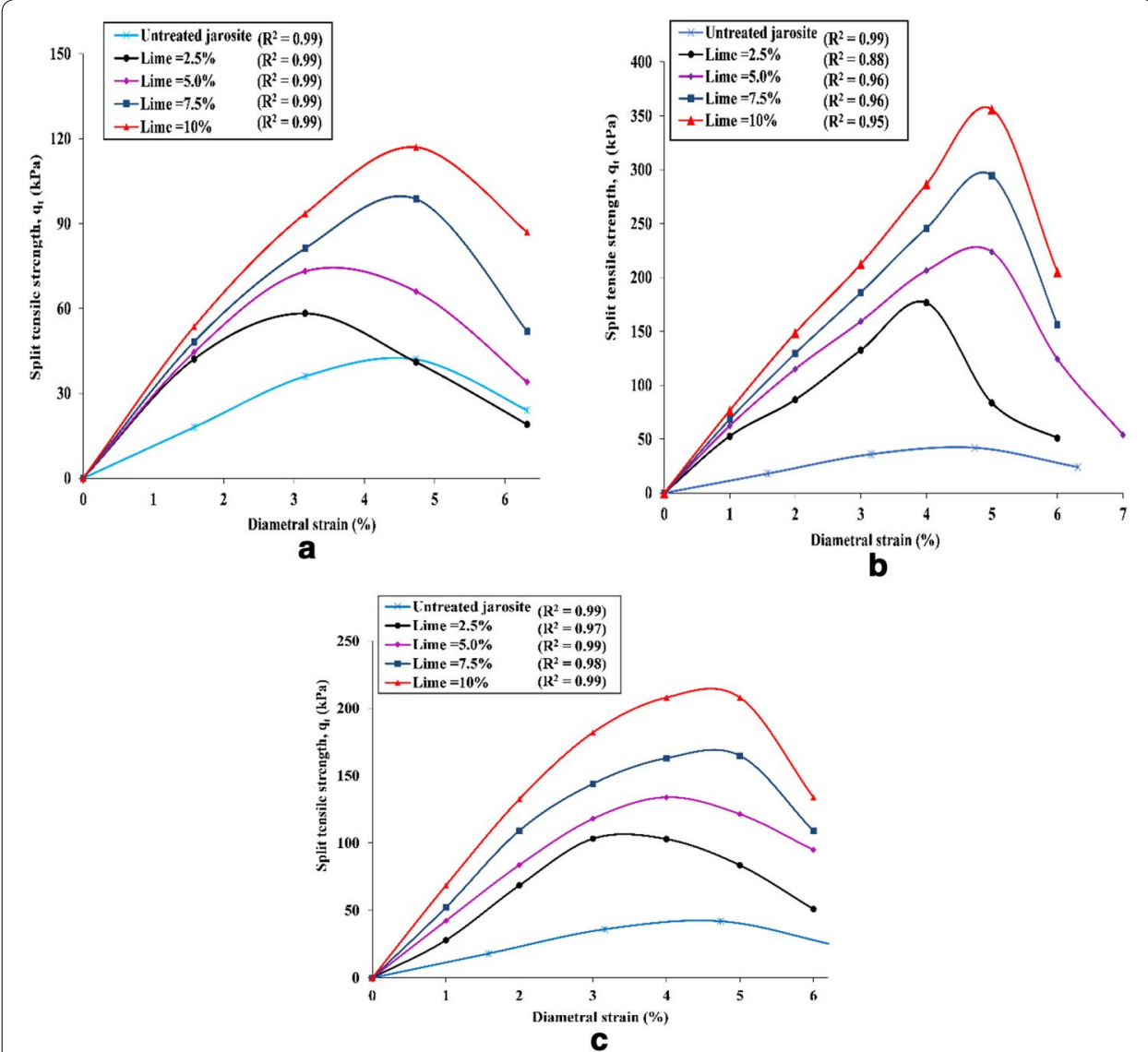

Fig. 5 Effect of lime content on Stress-Strain behaviour of split tensile samples cured at a 7, b 28, and $\mathbf{c}$ 90 days

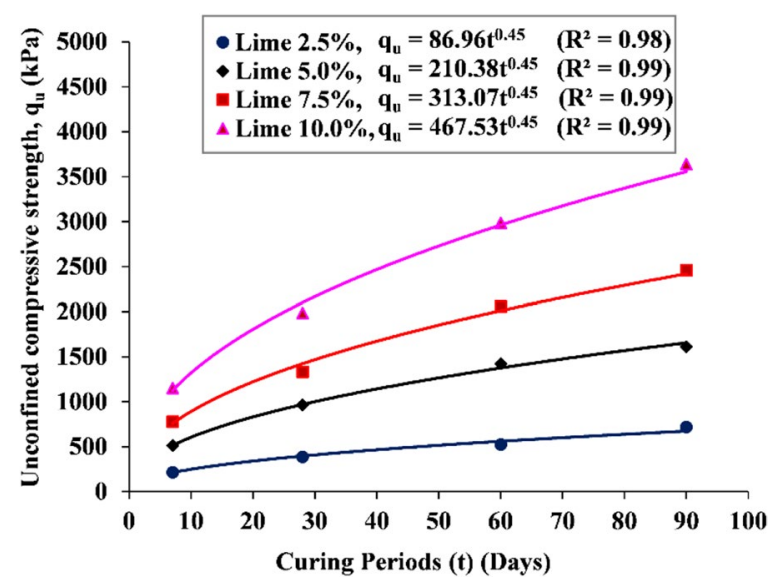

Fig. 6 Effect of lime content on UCS $\left(q_{u}\right)$ with curing periods

Factor $\mathrm{A}=$ a scalar coefficient influenced by type of strength test, being 44.22 for UCS and 7.07 for split tensile strength, and Factors $a=0.45$, and $b=1.0$ are unique scalars for both types of test. Now, the ratio $\mathrm{q}_{\mathrm{t}} / \mathrm{q}_{\mathrm{u}}$ can be written as (Eq. 4): 


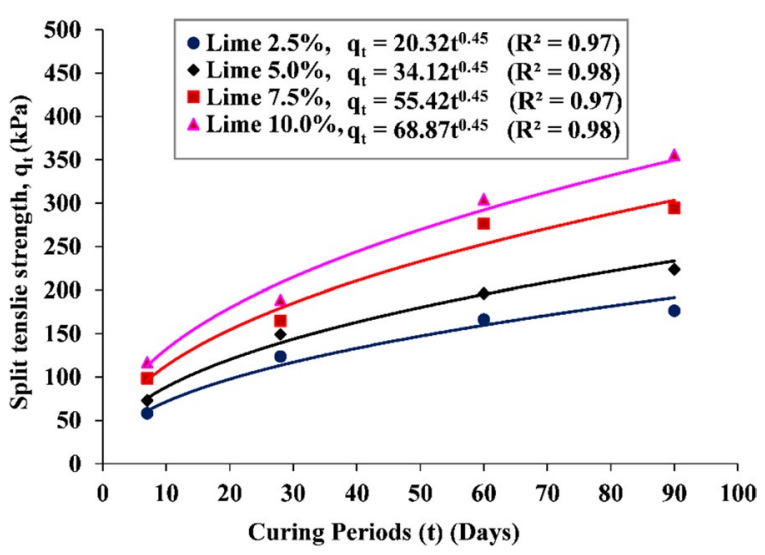

Fig. 7 Effect of lime content on split tensile strength $\left(q_{t}\right)$ with curing periods

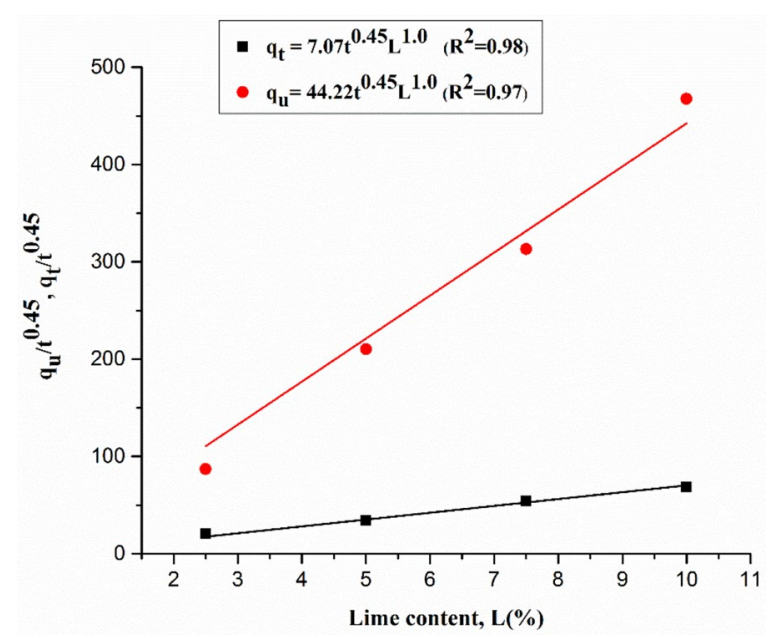

Fig. 8 Relationship between unconfined compressive strength $\left(q_{u}\right)$ and split tensile strength $\left(q_{t}\right)$ with various lime content $(\mathrm{L})$, and curing period $(\mathrm{t})$

$$
C=\frac{7.07(\mathrm{t})^{0.45}(\mathrm{~L})^{0.90}}{44.22(\mathrm{t})^{0.45}(\mathrm{~L})^{0.90}}=0.1598 \approx 0.16
$$

Thus, for all jarosite-lime blends, with curing period studied, it is be possible to establish the correlations, $\mathrm{q}_{\mathrm{t}} / \mathrm{q}_{\mathrm{u}}\left(\right.$ entitled as $\mathrm{C}^{\mathrm{r}}$ ), which is a unique scalar $\left[\mathrm{C}^{\circ}=0.16\right]$ (Eq. 4). This is independent of the curing period $(\mathrm{t})$, and lime content $(\mathrm{L})$. However, it is advisable that more studies should be required to validate these expressions with different types of materials such as soils, activators (binders), along with longer curing periods.

\section{Microstructural analysis}

Pieces from tested samples from strength tests with various lime content and curing period were further examined for their microstructural variations by analyzing scanning electron microscope (SEM), and energy-dispersive X-ray spectroscopy (EDX). It is perceived that the addition of lime to the jarosite, results in agglomeration. This 

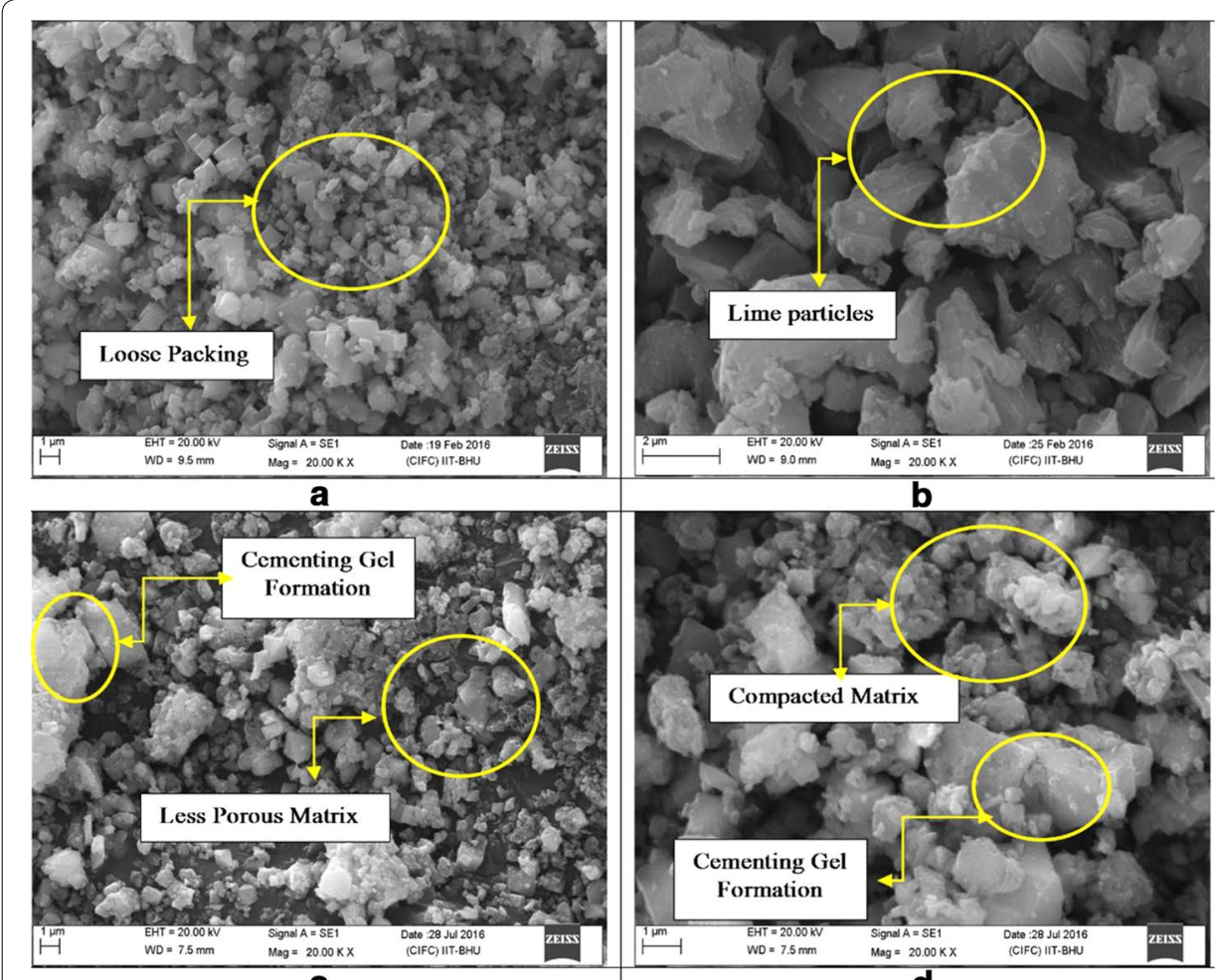

d

Fig. 9 SEM images (Magnification = $20 \mathrm{kx}$ ) of jarosite-lime blends $\mathbf{a}$ jarosite; $\mathbf{b}$ lime; $\mathbf{c}$ jarosite-lime blend (5\% lime and 90 days curing); d jarosite-lime blend (10\% lime and 90 days curing)

agglomeration of particles is attributed to the active/free aluminous and silicious minerals present in jarosite reacting with calcium found in lime to produce calcium silicates hydrate $[\mathrm{C}-\mathrm{S}-\mathrm{H}]$ and calcium aluminates hydrate $[\mathrm{C}-\mathrm{A}-\mathrm{H}]$ bonds.

The formation of above cementitious compounds can be explained by the following chemical reactions:

$$
\begin{aligned}
& \mathrm{Ca}(\mathrm{OH})_{2} \text { (ionization of hydrated lime) } \longrightarrow \mathrm{Ca}^{2+}+2(\mathrm{OH})^{-} \\
& \mathrm{Ca}^{2+}+(\mathrm{OH})^{-}+\mathrm{SiO}_{2} \text { (soluble silica) } \longrightarrow \text { Calcium silicate hydrate } \\
& \mathrm{Ca}^{2+}+(\mathrm{OH})^{-}+\mathrm{Al}_{2} \mathrm{O}_{3} \text { (soluble alumina) } \longrightarrow \text { Calcium aluminium hydrate }
\end{aligned}
$$

A typical SEM image of jarosite-lime blends has been shown in Fig. 9. Figure 9a illustrates the loosely packed (more porous) jarosite (untreated), Fig. 9b shows the SEM image of lime, Fig. 9c shows the influence of addition of lime (5\%) on jarosite at 90 days curing period that indicates a closed and less porous matrix (agglomeration) produced as compared to untreated jarosite, and Fig. 9d illustrates the influence of higher percentage of lime (10\%) on jarosite at 90 days curing period that indicates larger agglomeration (dance packing) of particles as cementing gel was produced.

Typical SEM-EDX images of selected blends of stabilized jarosite are shown in Fig. 10. From SEM-EDX studies, it is observed that the addition of lime to jarosite enhances the strength characteristics due to larger agglomeration of particles. The changes in strength 


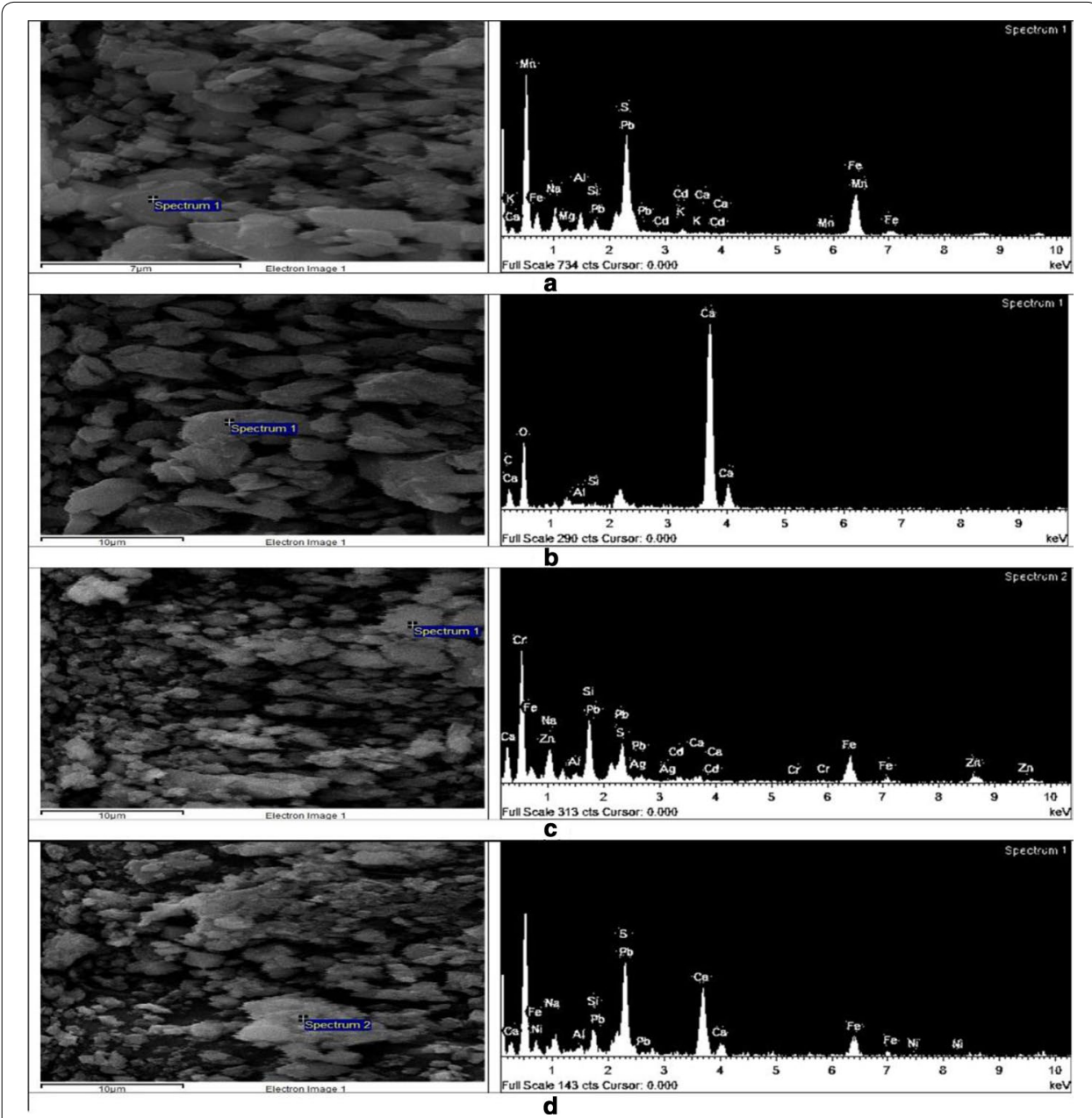

Fig. 10 SEM-EDX images of a jarosite; b lime; c jarosite-lime blend (5\% lime and 90 days curing); $\mathbf{d}$ jarositelime blend (10\% lime and 90 days curing)

Table 3 Effect of lime on Ca:Si and Si:Al ratio (SEM-EDX)

\begin{tabular}{|c|c|c|c|c|c|c|c|}
\hline \multirow[t]{3}{*}{ Samples } & \multirow[t]{3}{*}{ Proportions (\%) } & \multicolumn{3}{|c|}{$\mathrm{Ca} / \mathrm{Si}$} & \multicolumn{3}{|c|}{$\mathrm{Si} / \mathrm{Al}$} \\
\hline & & \multicolumn{6}{|c|}{ Curing periods (days) } \\
\hline & & 7 & 28 & 90 & 7 & 28 & 90 \\
\hline Jarosite & Untreated & 0.11 & 0.11 & 0.11 & 0.49 & 0.49 & 0.49 \\
\hline \multirow[t]{2}{*}{ Jarosite-Lime } & $J+5.0 \% \mathrm{~L}$ & 0.68 & 1.39 & 1.97 & 2.58 & 1.89 & 1.16 \\
\hline & $J+10 \% \mathrm{~L}$ & 1.11 & 3.04 & 4.13 & 4.65 & 3.16 & 2.78 \\
\hline
\end{tabular}

characteristics can be studied by the variation in $\mathrm{Ca}: \mathrm{Si}$ and $\mathrm{Si}: \mathrm{Al}$ ratios. Table 3 shows the variation in $\mathrm{Ca}: \mathrm{Si}$ and $\mathrm{Si}: \mathrm{Al}$ ratios of selected jarosite-lime blends.

From Table 3, it is perceived that the addition of lime to jarosite leads to an increase in $\mathrm{Ca}: \mathrm{Si}$ ratio and a decrease in $\mathrm{Si}: \mathrm{Al}$ ratio with increase in curing periods. The increase in $\mathrm{Ca}$ :Si ratio confirms the formation of various cementing compound such as [C-S-H], $[\mathrm{C}-\mathrm{A}-\mathrm{H}]$ and $[\mathrm{C}-\mathrm{S}-\mathrm{A}-\mathrm{H}]$, which are primarily involved in the enhancement of strength 
characteristics. Similar findings have also been reported by Kumar and Datta [26], Kumar et al. [27].

\section{Applications}

To choose the optimum amount of lime with appropriate curing period for the desired compressive or tensile strength of jarosite-lime blend, the outcomes illustrate by Eqs. 1, 2 may be useful to an engineer. It may be advocated that the tensile strength and unconfined compressive strength of lime stabilized jarosite are interrelated and the ratio $\mathrm{q}_{\mathrm{t}} /$ $\mathrm{q}_{\mathrm{u}}$ is associated by a scalar (0.16) (Eq. 4). This scalar is independent of curing period, and lime content. Thus, from these dosage methodologies, an engineer/user, can target either tensile strength or compressive strength to get the desired result. Furthermore, as per the guidelines of US Army Corp of Engineers manual [40] for minimum requirements of UCS of lime stabilized materials to be used as a sub grade, sub base and base material in the design of flexible as well as rigid pavement, it is revealed that the lime stabilized material should have the satisfactory strength to be used in sub base course or sub base i.e. UCS up to 1725 and $1380 \mathrm{kPa}$ and in base course up to 5170 and $3450 \mathrm{kPa}$ for flexible and rigid pavement, respectively. On a closer look of Fig. 4c, it is revealed that jarosite blended with $10 \%$ lime and at 90 days curing period has UCS of $3641 \mathrm{kPa}$. Thus, it can be advocated that lime stabilized jarosite blends have the adequate strength to be used as a construction material in sub grade and sub base course for both types of pavement, and base course for rigid pavement design only.

\section{Conclusion}

In this study, lime has been used to enhance various geotechnical properties of jarosite waste. The study also includes the mineralogical characteristics of lime stabilized jarosite with various curing periods. Based on the outcomes, subsequent conclusions have been drawn:

- The addition of lime influences the compaction parameters. There is an increase in optimum moisture content (OMC), and a decrease in the maximum dry unit weight (MDD) with an increase in lime content.

- The unconfined compressive strength as well as split tensile strength increase significantly with an increase in lime content and with increasing curing period. Lime acts as an activator that enhances the strength.

- The microstructural study (SEM and EDX) also reveals the agglomeration of particles, which further validates the increase in strength with the addition of higher lime content and longer curing periods.

- Relationships between $\mathrm{q}_{\mathrm{u}}$ and $\mathrm{q}_{\mathrm{t}}$ with various lime content $(\mathrm{L})$ and curing period ( $t$ ) have been proposed that will help the engineer or user to choose the optimum amount of lime against targeted compressive or tensile strength of jarosite-lime blends.

- A unique scalar from $\mathrm{q}_{\mathrm{t}} / \mathrm{q}_{\mathrm{u}}$ ratio (independent of lime content and curing period) has been formulated that will enhancing the possibility to concentrate on any one strength, tensile or compressive strength, and find out the other one. 
- Jarosite stabilized with $10 \%$ lime has the satisfactory strength to be used in sub base course or subgrade of both the types of pavement, and base course of rigid pavement design.

Authors' contributions

CG and AP carried out the parametric studies on variables controlling the strength of lime stabilized jarosite waste and drafted the manuscript. All authors read and approved the proof of final manuscript.

Competing interests

The authors declare that they have no competing interests.

Ethics approval and consent to participate

Not applicable.

\section{Appendix}

\section{Practical calculation example}

You have browsed an ABC apparel company's website. You found a clothing item of your interest and were about to purchase it. Then, you realized that the ABC company did not provide any statement in compliance with the California Transparency in Supply Chains Act in their website.

Illustration of calculation of a specific amount of lime (L) to reach a target value of $\mathrm{q}_{\mathrm{u}}$. Target value of $\mathrm{q}_{\mathrm{u}}=1000 \mathrm{kPa}$ and established curing period $(\mathrm{t})=7,28$ and 90 days. On the basis of availability and practical implication, choose all phases of curing period and corresponding to these, find the appropriate amount of lime $(\mathrm{L})$ to achieve a target value of $\mathrm{q}_{\mathrm{u}}$.

- Choose $\mathrm{t}=7$ days

Solution for L, obtained by Eq. (1) as L $=9.86 \%$

- Choose $\mathrm{t}=28$ days

Solution for L, obtained by Eq. (1) as $\mathrm{L}=5.28 \%$

- Choose $\mathrm{t}=90$ days

Solution for L, obtained by Eq. (1) as L = 3.12\%.

\section{Publisher's Note}

Springer Nature remains neutral with regard to jurisdictional claims in published maps and institutional affiliations.

Received: 18 November 2017 Accepted: 20 April 2018

Published online: 27 April 2018

\section{References}

1. Asokan P, Saxena M, Asolekar SR (2005) Jarosite characteristics and its utilisation potentials. J Total Environ 359:232-243

2. Asokan P, Saxena M, Asolekar SR (2006) Hazardous jarosite use in developing non-hazardous product for engineering application. J Hazard Mater 137:1589-1599

3. Asokan P, Saxena M, Asolekar SR (2010) Recycling hazardous jarosite waste using coal combustion residues. Mater Charact 61:1342-1355

4. Asokan P, Saxena M, Asolekar SR (2011) Waste to wealth-cross sector waste recycling opportunity and challenges. Can J Environ Constr Civil Eng 2(3):14-23

5. ASTM (1995) D-3967-95a: standard test method for splitting tensile strength of intact rock core specimens. American Society for Testing of Materials, Pennsylvania

6. ASTM (2000) D4318-00: standard test methods for liquid limit, plastic limit, and plasticity index of soils. American Society for Testing of Materials, Pennsylvania 
7. ASTM (2000) D854-00: standard test methods for specific gravity of soil solids by water pycnometer. American Society for Testing of Materials, Pennsylvania

8. ASTM (2004) D6913-04: standard test methods for particle size distribution (gradation) of soils using sieve analysis. American Society for Testing of Materials, Pennsylvania

9. ASTM (2006) D2166-06: standard test method for unconfined compressive strength of cohesive soil. American Society for Testing of Materials, Pennsylvania

10. ASTM (2007) D422-63: standard test methods for particle size analysis of soils. American Society for Testing of Materials, Pennsylvania

11. ASTM (2011) D2487-11: standard practice for classification of soils for engineering purposes (Unified Soil Classification System). American Society for Testing of Materials, Pennsylvania

12. ASTM (2012) D698-12e1: standard test methods for laboratory compaction characteristics of soil using standard effort. American Society for Testing of Materials, Pennsylvania

13. Arora V, Sachdeva SN, Aggarwal P (2015) Effect of use of Jarosite on workability and early age strength of concrete. Int J Comput Math Sci IJCMS 4:136-144

14. Brandl H (1981) Alteration of soil properties by stabilization with lime. In: Proc. 10th International conference on soil mechanics and foundation engineering, vol 3. p 587

15. Chen TT, Dutrizac JE (2000) A mineralogical study of jarosite products for the stabilization of jarosite residues for disposal. TMS 2000:917-933

16. Cheilas A, Katsioti M (2007) Impact of hardening conditions on to stabilized/solidified products of cement—sewage sludge_-jarosite/alunite. Cement Concr Compos 29:263-269

17. Ding M, Geusebroek M, Sloot HA (2002) Self-sealing isolation and immobilization-a geochemical approach to solve the environmental problem of waste acidic jarosite. Appl Geochem. 17:93-103

18. Eades JL, Grim RE (1966) A quick test to determine lime requirements for soil stabilization. Highway Research Record No. 139. Highway Research Board, Washington D.C., pp 61-72

19. Gupta C, Prasad A (2018) Strength and durability of lime-treated jarosite waste exposed to freeze and thaw. J Cold Regions Eng 32(1):04017025. https://doi.org/10.1061/(ASCE)CR.1943-5495.0000154

20. Gupta C, Prasad A (2018) A parametric strength study of jarosite waste. In: Proceedings of the institution of civil engineers: waste and resource management. (Published online: February 6, 2018). https://doi.org/10.1680/ jwarm.17.00041

21. Hage JLT, Schuiling RD (2000) Comparative column elution of jarosite waste and its autoclaved product-evidence for the immobilization of deleterious elements in jarosite. Miner Eng 13(3):287-296

22. Holtz RD, Kovacs WD (1981) An introduction to geotechnical engineering. Prentice-Hall Inc, Englewood Cliffs, pp $356-360$

23. IS: 2911-3 (1980) Determination of differential free swell index soils. Methods of tests for soil. Bureau of Indian Standards, New Delhi

24. Kalkan E, Akbulut S (2004) The positive effects of silica fume on the permeability, swelling pressure and compressive strength of natural clay liners. Eng Geol 73(1-2):145-156

25. Katsioti M, Boura P, Tsakiridis PE, Agatzini S, Oustadakis P (2005) Use of jarosite/alunite precipitate as a substitute for gypsum in Portland cement. Cement Concr Compos 27:3-9

26. Kumar S Datta RK (2014) Microstructural development in bentonite modified with lime and phoshpogypsum. In: International multi track conference on science, engineering and technology innovations, pp 126-129

27. Kumar S, Dutta RK, Mohanty B (2015) Potential of bentonite-lime-mix modified with phosphogypsum and reinforced with sisal fibres. PeriodicaPolytechnica Civil Eng 59(2):143-154. https://doi.org/10.3311/PPci.7733

28. Makhatha ME, Ndou MO Nheta W (2015) Characterisation of jarosite, fly ash and clay for their possible usage in the construction industry. In: Proceedings of the world congress on mechanical, chemical, and material engineering (MCM 2015), Barcelona, Spain, pp 1-9

29. Mehra P, Chandra R, Skariah B (2016) Assessment of durability characteristics of cement concrete containing jarosite J Clean Prod 119:59-65. https://doi.org/10.1016/j.jclepro.2016.01.055

30. Mehra P, Chandra R, Skariah B (2016) Properties of concrete containing jarosite as a partial substitute for fine aggregate. J Clean Prod 120:241-248. https://doi.org/10.1016/j.jclepro.2016.01.015

31. Mymrin V, Vaamonde VA (1999) New construction materials from Spanish jarosite processing wastes. Miner Eng 12(11):1399-1402

32. Mymrin VA, Ponte HA, Impinnisi PR (2004) Potential application of acid jarosite wastes as the main component of construction materials. Constr Build Mater 19:141-146. https://doi.org/10.1016/j.cemconcomp.2006.12.005

33. Sherwood PT (1993) Soil stabilisation with cement and lime: state of the art review. HMSO Publication, UK

34. Sinha AK, Havanagi VG, Ranjan A, Mathur S, Arora VK (2011) Feasibility study of Jarofix waste material for road construction. In: Proceedings of Indian geotechnical conference, Kochi, Vol 1, pp 685-688

35. Sinha AK, Havanagi VG, Arora VK, Mathur S (2012) Design, construction \& evaluation of jarofix embankment and sub grade layers. Int J Environ Eng Res 1(3):97-103

36. Sinha AK, Havanagi VG, Ranjan A, Mathur S (2013) Geotechnical characterization of jarosite waste material for road construction. In: Proceedings of Indian geotechnical conference. pp 22-24

37. Singh V (1996) Technological innovation in the zinc electrolyte purification process of a hydrometallurgical zinc plant through reduction in zinc dust consumption. Hydrometallurgy 40:247-262

38. Sridharan A, Sivapullaiah PV (2005) Mini compaction test apparatus for fine grained soils. Geotech Test J 28(3):240-246

39. Vyas AK (2011) Solidification-stabilization technique for metal bearing solid waste from zinc industry — a case study. Proceeding of international conference on environmental and computer science (IPCBEE), vol 19 pp 151-155

40. United Facilities Criteria (3-250-11). Soil stabilization for pavements. TM 5-822-14/AFJMAN 32/1019 (2004). http:// wbdg.org/FFC/DOD/UFC/ufc_3_250_11_2004.pdf. Accessed 10 Jul 2017

41. Yıldız M, Soğancı AS (2012) Effect of freezing and thawing on strength and permeability of lime-stabilized clays. Scientialranica 19(4):1013-1017. https://doi.org/10.1016/j.scient.2012.06.003 